\title{
Pengembangan Kambing Etawa dalam Rangka Sukses Program Desa Wisata
}

\author{
Mohamad Muhajir, Zaini Muchlis \\ Prodi Pendidikan bahasa Arab, Fakultas Pendidikan Bahasa, Universitas Muhammadiyah Yogyakarta, \\ Prodi Ilmu Ekonomi Fakultas, Ekonomi dan Binis, Universitas Muhammadiyah Yogyakarta \\ J. Brawijaya Taman Tirto Kasihan Bantul Yogyakarta \\ Email: hajirmesir@umy.ac.id \\ DOI: $10.18196 / p p m .32 .226$
}

\begin{abstract}
Abstrak
Magelang memiliki alam luas yang subur dengan tumbuh-tumbuhan dan tanaman-tanaman pertanian yang membentang serta menyimpan pesona kekayaan alam yang indah. Hal ini berpotensi melahirkan nilai ekonomi yang tinggai bagi masyarakat sekitar. Dusun Rejosari yang berada di Desa Mrangen menampilkan pesona alam yang menawan yang sekaligus menjadi daya dongkrak tumbuhnya perekonomian masyarakat sekitar. Pengabdian ini bertujuan untuk memberikan penyuluhan dan pemahaman kepada masyarakat terkait pengembangan peternakan kambing etawa mengingat begitu besarnya potensi alam yang mendukung. Kehadiran gagasan dan pikiran besar dari desa untuk menjadikan Mrangen sebagai desa wisata sudah dikerjasamakan dengan kampus Universitas Muhammadiyah Yogyakarta dengan kontrak lima tahun. Kondisi ini menuntut warga menggali potensi-potensi yang bisa diberdayakan sehingga menjadi komoditi yang layak dan patut diberikan perhatian. selanjutnya hal tersebut bisa bdikembangkan dan akan menjadi daya tarik tersendiri untuk diintegrasikan dengan potensi-potensi yang ada di Desa Mrangen umumnya dan Dusun Rejosari khususnya.
\end{abstract}

Kata Kunci; Kambing Etawa, Nilai Ekonomi, Desa Wisata,

\section{Pendahuluan}

Dusun Rejosari merupakan salah satu dusun yang berada di kawasan lereng Merapi, tepatnya di Desa Mranggen, Kabupaten Magelang. Dusun Rejosari terbagi menjadi tiga RT. Dusun Rejosari dapat ditempuh dengan waktu kurang lebih 1,5 jam dari Kampus Universitas Muhammadiyah Yogyakarta. Kondisi geografis Dusun Rejosari adalah di lereng Merapi. Mayoritas masyarakat Dusun Rejosari bekerja sebagai petani dan peternak serta penambang pasir. Hasil dari pertanian dusun tersebut sebagian besar adalah salak. Selain itu warga dusun juga beternak kambing etawa dan sebagaian lagi bekerja sebagai penambang pasir di titik-titik penambangan pasir Gunung Merapi. Selain dalam bidang pertanian, Dusun Rejosari juga merupakan dusun terbersih. Dusun Rejosari telah memenangkan lomba dusun terbersih sebanyak dua kali. Dusun Rejosari juga terkenal sebagai Desa Adat karena Dusun Rejosari selalu mengadakan upacara adat setiap waktu-waktu tertentu berdasarkan kalender Jawa.

Desa Mrangen yang di dalamnya ada Dusun Rejosari telah membuat dan mencanangkan program besar, yaitu pengembangan desa wisata dengan melihat dan menggali potensi-potensi internal yang ada yang terdapat di Dusun Rejosari khususnya dan Desa Mrangen pada umumnya. Desa wisata adalah sebuah kawasan pedesaan yang memiliki beberapa karakteristik khusus untuk menjadi daerah tujuan wisata.1 Pada prinsipnya, pengembangan suatu desa menjadi desa wisata haru smemenuhi bebrapa prinsip, yaitu pengidentifikasian terhadap unsur-unsur potensi yang ada di desa dan penentuan desa wisata harus diimbangi dengan pemahaman karakteristik serta tatanan budaya masyarakat. Hal ini dimaksudkan agar dapat dimanfaatkan dalam pengembangan aspek perekonomian desa tersebut. Wilayah yang bisa dikembangkan menjadi desa wisata adalah wilayah yang baik dari segi ekonomi, sosial budaya, lingkungan fisik alam, mempunyai ciri khas yang nonurban, dan

${ }^{1}$ Faris Zakaria, Rima Dewi Suprihardjo, Konsep Pengembangan Kawasan Desa Wisata di Desa Bandungan Kecamatan Pakong Kabupaten Pamekasan, Jurnal Teknik POMITS Vol. 3, No.2, (2014) 
mempunyai ciri kehidupan tradisional yang unik. Klasifikasi desa wisata memiliki karakteristik tertentu, antara lain desa wisata budaya, desa wisata pertanian, desa wisata pendidikan, desa wisata fauna, desa wisata kerajinan, dan desa wisata alam. Desa wisata adalah suatu wilayah pedesaan yang menawarkan keaslian baik dari segi sosial budaya, adat-istiadat, keseharian, arsitektur tradisional, dan struktur tata ruang desa yang disajikan dalam suatu bentuk integrasi komponen pariwisata, seperti atraksi, akomodasi, dan fasilitas pendukung2

Sebagian besar penduduk Dusun Rejosari bekerja sebagai petani, sebagian lagi berternak, dan ada yang menjadi penambang pasir. Karakter kehidupan gotong-royong masyarakat masih sangat kental dan kuat. Hamparan lahan pertanian salak, jagung, padi, jejeran kelapa, dan kandang-kandang kambing etawa yang dikelola oleh masyarakat secara tradisional sangat menawarkan keindahan dan potensi yang sangat bisa untuk diberdayakan dan dikembangkan sebagai modal untuk menuju program desa wisata. Kehidupan sosial antarwarga sangat rukun, damai, dan didukung lingkungan yang aman. Adanya berbagai daya dukung yang potensial di Dusun Rejosari yang berada di dalam Desa Mrangen ini dapat dikembangkan menjadi desa/dusun wisata tanpa meninggalkan nilai-nilai kehidupan dan kearifal lokal yang ada.

Berkaitan dengan pengembangan kambing etawa, kebanyakan penduduk desa menjalankan usaha beternak kambing secara rumahan dan tradisional sehinggga kurang maksimal.3 Apabila dikelola dengan konsep modern dan sistem gotong-royong atau kongsi dengan menggunakan jalur komunitas, hasilnya akan berbeda. Kita bisa dengan mudah menemukan banyak kandang kambing di samping rumah warga desa. Sistem yang digunakan adalah usaha sampingan yang tidak dikerjakan secara intensif. Mereka beternak kambing hanya beberapa ekor tanpa target omset apa pun. Padahal, kalau ditekuni secara modern dan serius, potensi usaha peternakan kambing di desa sangatlah besar. Supaya usaha ternak kambing dapat cepat berhasil, digunakan cara beternak kambing secara modern dan professional, seperti fermentasi pakan ternak kambing yang termasuk cara beternak kambing yang baik dan benar. 4

Dari analisis permasalahan pengembangan perternakan kambing etawa yang terintegrasi dengan konsep Desa Wisata Mrangen yang dialami oleh pengelola Desa Mrangen ditemukan beberapa masalah. Pertama, tata kelola peternakan kambing etawa yang terintegrasi dengan potensi perpaduan wisata belum serius dan fokus digarap, misalnya pembuatan varian-varian rasa pada pengolahan susu kambing etawa yang sudah diolah dengan higienis. Kedua, pengelolaan pengembangan kambing yang terintegrasi dengan konsep desa wisata masih bersifat pribadi dan belum menjadi bagian dari sumber ekonomi masyarakat sekitar yang dikelola secara kolektif guna menunjang peta konsep desa wisata. Ketiga, pemerintah belum mencarikan investor yang mau membangun dusun wisata ini karena usaha beternak kambing etawa memerlukan modal besar, khususnya untuk pembuatan kandang kambing. Biaya pembuatan kandang kambing tergantung luasnya. Biasanya Rp1,5 juta. Selain itu, perlu mengadakan pembelian bibit kambing jantan dan betina siap kawin dan biaya lainnya. Harga bibit kambing jantan Rp 3 juta, sedangkan harga bibit kambing betina sekitar Rp 2 juta.5 Keempat, banyak kader-kader daerah telah dihasilkan dari dusun ini, tetapi mereka lebih

\footnotetext{
${ }^{2}$ Ibid.

${ }^{3}$ Rusdi 1, Wahidul Basri 2, Aldi Frinaldi 3, Uun Lionar 4, Budidaya Kambing Etawa di Jorong Padang Ambacang Nagari Batu Balang Kecamatan Harau Kabupaten Lima Puluh Kota, Suluah Bendang: Jurnal Ilmiah Pengabdian Kepada Masyarakat Vol.19, No.3, 2019 ${ }^{4}$ Ibid 
memilih pergi ke kota untuk mencari pekerjaan karena dusun ini tidak menjanjikan kehidupan yang lebih baik.

Pengelolaan dan pengembangan peternakan kambing etawa dalam usaha pembuatan konsep besar desa wisata yang selama ini dirintis di Desa Mrangen masih belum didokumentasikan dan dikelola dengan baik. Administrasi keuangan, publikasi, manajemen, dan peta konsep besar desa wisata masih belum dikondisikan dengan baik oleh pengelola. Hal ini disebabkan keterbatasan pengetahuan dan wawasan, khususnya dalam pengembangan ternak kambing etawa berbasis integrasi desa wisata. Bertolak dari luasnya permasalahan di atas, tema "Pengembangan Peternakan Kambing Etawa dalam Rangka Sukses Desa Wisata" sangat menarik untuk diangkat melihat begitu kompleksnya permasalahan yang ada di Dusun Rejosari, Desa Mrangen.

Metode atau konsep yang digunakan sebagai pemecahan masalah peternakan kambing etawa di Dusun Rejosari, Desa Mrangen adalah dengan pendekatan terpadu, yang meliputi bebrapa hal. Satu, pembinaan dan pemahaman wawasan peternak dalam konsep berbasis desa wisata melalui pengembangan peternakan kambing etawa. Kedua, optimalisi lahan dan kandang dengan sentuhan ilmu dan bahan berbasis lokal sesuai potensi yang ada. Ketiga, mendatangkan ahli sekaligus aplikasi penerapan ilmu dan penerapan bahan berbasis lokal.

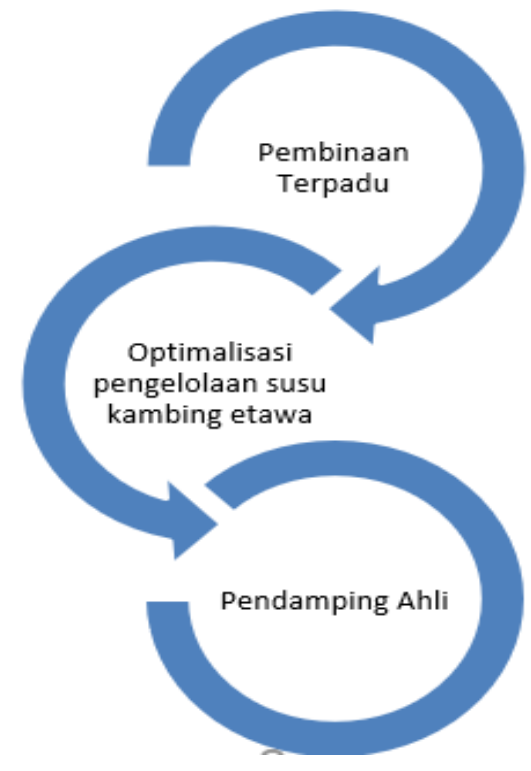

Gambar 1. Keterpaduan Pertanian-Peternakan Holistik

Penyelesaian masalah diusulkan untuk mengatasi beberapa persoalan di atas, yaitu pertama, optimalisasi peternakan kambing Etawa yang terintegrasi dengan konsep program berbasis desa wisata dengan kerja sama antara pemerintah desa dan LP3M Univeristas Muhammadiyah Yogyakarta dengan kontrak lima tahun ke depan. Kedua, pengembangan pengelolaan hasil susu kambing etawa untuk diolah menjadi komoditi ekonomi peternak dengan membuat olahan kefir susu kambing etawa, dodol susu kambing etawa, krupuk kambing etawa yoghurt, dan lain sebagainya. Ketiga, mencarikan investor swasta yang siap bekerja sama memajukan usaha susu kambing etawa yang terintegrasi dengan konsep program desa wisata. Kempat, merekrut sumber daya manusia setempat sesuai dengan kompetensi keilmuan yang dimiliki dan kecenderungannya masing-masing, terlebih lagi yang paham dengan pengintegrasian konsep desa wisata yang berbasis pada pengembangan kambing etawa karena masyarakat saat ini seharusnya mampu mendapatkan keuntungan lebih banyak dari pariwisata di wilayahnya. Pariwisata berbasis komunitas (community based tourism) adalah sebuah konsep yang 
menekankan masyarakat untuk mampu mengelola dan mengembangkan objek wisata mereka sendiri.6

Tujuan penyuluhan peternakan kambing etawa ini dapat disampaikan sebagai berikut: pertama, memberikan wawasan pengembangan peternakan kambing etawa melalui penyuluhan dan memberikan contoh model pengelolaan untuk dikerjakan para peternak kambing etawa; kedua, meningkatkan kualitas peternakan kambing etawa dengan cara memberikan variasi pengelolaan susu kambing etawa untuk menjadi varian-varian yang punya nilai ekonomis tinggi; ketiga, menambah wawasan pengelolaan usaha peternakan melalui penyuluhan; keempat, pemetaan sumber daya manusia yang ada.

Program pengabdian kepada masyarakat melalui penyuluhan ini dapat bermanfaat bagi bebrapa pihak. Pertama, peternak kambing etawa, yakni dapat menambah wawasan terkait pengelolaan susu kambing untuk jadikan komoditasi ekonomi. Kedua, tim pelaksana, yakni dapat menambah wawasan pengetahuan dan pengalaman mengembangkan peternakan kambing etawa. Ketiga, lembaga penyelenggara, yakni menambah mitra kerja dengan masyarakat yang dapat memberikan kepercayaan untuk saling membantu secara sinergis.

\section{Metode Pelaksanaan}

Metode pelaksanaan program ini ini terbagi menjadi beberapa bagian, yaitu pertama, metode observasi (pengamatan). Pengamatan adalah alat pengumpulan data yang dilakukan dengan cara mengamati dan mencatat secara sistematik fenomena yang ada di Dusun Rejosari, Desa Mrangen. Pada metode pegamatan ini, peneliti terjun langsung untuk mengamati secara langsung permasalahan yang ada di lokasi dan fenomena-fenomena yang terjadi di peternakan kambing etawa di Dusun Rejosasri, Desa Mrangen, Kabupaten Magelang.

Tabel 2. MMetode pelaksanaan program

\begin{tabular}{|c|c|c|}
\hline No & Program & Metode Pelaksanaan \\
\hline 1. & $\begin{array}{l}\text { Perkembangbiakan } \\
\text { kambing PE }\end{array}$ & $\begin{array}{ll}\text { - } & \text { Observasi tentang potensi dan masalah desa. } \\
\text { - } & \text { Pendekatan dan wawancara dengan kepala dukuh, ketua RT, dan warga setempat. } \\
\text { - } & \text { Pengajuan kerja sama dengan narasumber yang } \\
& \text { berkecimpung dibidangnya. } \\
\text { - } & \text { Penetapan jadwal penyuluhan. } \\
\text { - } & \text { Pemberian informasi kepada masyarakat tentang adanya penyuluhan. } \\
\text { - } & \begin{array}{l}\text { Pelaksanaan penyuluhan perkembangbiakan kambing dengan } \\
\text { narasumber. }\end{array}\end{array}$ \\
\hline
\end{tabular}

Metode yang kedua adalah metode interview atau metode wawancara, yaitu suatu metode pengumpulan data yang dilakukan melalui tanya jawab secara langsung dengan sumber data. Interview merupakan alat pengumpulan informasi dengan cara mengajukan pertanyaan secara lisan untuk dijawab secara lisan juga. Ciri utama dari interview adalah kontak langsung dengan tatap muka antara pencari informasi dan sumber informasi. Dalam wawancara secara mendalam ini dilakukan peneliti terhadap informan yang menjadi objek dari penelitian ini, yaitu kepala desa, kepada dusun, dan warga peternak kambing etawa di Dusun Rejosari. Wawancara ini bertujuan untuk memperoleh informasi yang ada relevansinya dengan pokok persoalan program

\footnotetext{
${ }^{6}$ Fildzah A'inun N, Hetty Krisnani, \& Rudi Saprudin Darwis, Pengembangan desa wisata melalui konsep community based tourism, Prosiding
} Penelitian dan Pengabdian kepada Masyarakat, Unpad November 2015 
Metode yang ketiga adalah metode dokumentasi, yaitu sumber data yang berasal dari dokumen foto-foto dan semisalnya. Metode dokumentasi ini merupakan salah satu bentuk pengumpulan data yang paling mudah karena hanya mengamati benda mati dan apabila mengalami kekeliruan mudah untuk merevisinya karena sumber datanya tetap dan tidak berubah.

\section{Hasil Pembahasan}

Metode pemeliharaan ternak dan penanganan yang baik pada saat pemerahan dan pascapemerahan merupakan faktor penting untuk menghasilkan susu kambing yang aman, sehat, utuh, dan halal. Pemeirntah telah menetapkan standar khusus untuk suatu produk pangan asal hewan, tetapi standar khusus untuk kualitas susu kambing saat ini belum tersedia. Persyaratan susu segar dapat mengacu pada Standar Nasional Indonesia (SNI) No. 7388-2009. ${ }^{7}$ Pada umumnya, kambing etawa diperah dua kali sehari, yakni pagi dan sore. Frekuensi pemerahan yang dua kali sehari didasarkan pada kemampuan berproduksi. Pada umumnya, kemampuan berproduksi kambing-kambing perah di Indinesia masih rendah. Frekuensi pemerahan yang semakin sering akan memberi rangsangan kepada kambing untuk memproduksi susu lebih banyak. Akan tetapi, frekuensi pemerahan harus disamakan dengan frekuensi pemberian pakan, terutama kosentrat. Apabila pemerahan dilakukan tiga kali sehari semalam, pemberian pakan pun harus tiga kali sehari semalam.

Bersama dengan Pak Suyono, selaku Kepala Dusun Rejosari, tim mengadakan koordinasi dan mendapatkan kesepakatan agar dapat membantu meyakinkan kembali masyarakat Rejosari untuk mengolah susu kambing etawa. Akan tetapi, daripada mengolah sesuatu yang di dusun tetangga sudah ada, lebih baik menciptakan inovasi baru yang ke depannya diharapkan menjadi sebuah ikon Dusun Rejosari sehingga menjadi ciri khasdan sesuai dengan Program Desa Wisata Desa Mrangen.

Gambar 2 : Gambar 2. Koordinasi dengan dusun kaitan teknis pelaksanaan kegiatan

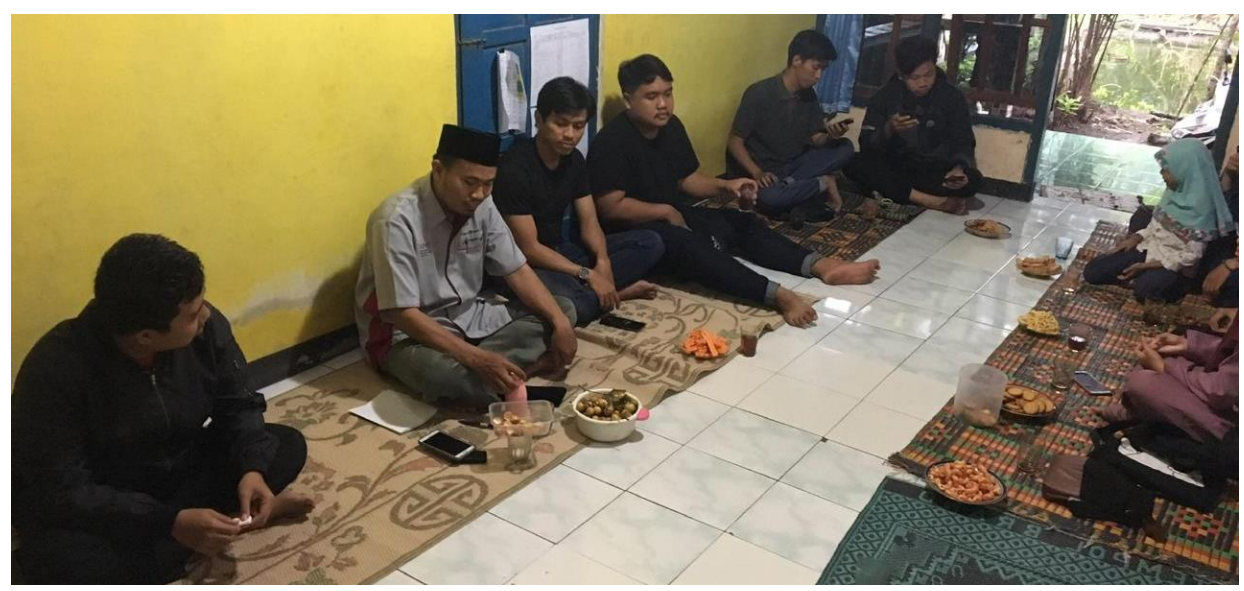

Pengelolaan susu kambing etawa merupakan hal yang baru bagi Desa Mranggen. Saat mencipatakan hal yang baru akan selalu ditemukan dinamika baru juga. Bagi dusun ataupun desa, langkah pertama yang dilakukan adalah berusaha mengenalkan program pelatihan yang masih baru kepada warga Dusun Rejosari.

${ }^{7}$ Zain, W. N. Kualitas Susu Kambing Segar di Peternakan Umban Sari dan Alam Raya Kota Pekanbaru, Jurnal Peternakan Vol. 10. No. 1. Februar 2013 (24-30. ISSN 1829-8729. 
Topografi wilayah Dusun Rejosari sebagian ada yang peternak kambing etawa. Setiap peternak kambing etawa melakukan pemerahan tiga kali sehari semalam dan pemberian hijauan dilakuakan minimal tiga kali dalam sehari semalam. Harus tetap diperhatikan supaya jarak pemerahan pertama dan kedua adalah 8 jam. Misalnya, jika pemerahan pertama dilakukan pada jam 07:00, pemerahan kedua dilakukan pada jam 15:00. Hal ini dilakukan supaya mendapatkan produksi susu yang maksimal. Pemberian pakan, pakan suplemen, dan air minum dilakukan setiap $1 / 2$ jam $-3 / 4$ jam sebelum pemerahan. Pemberian hijauan dilakukan dengan cara bertahap setiap $1 \frac{1}{2}$ jam setelah pemerahan. Pemberian hijauan secara bertahap artinya sedikit demi sedikit secara berkelanjutan.

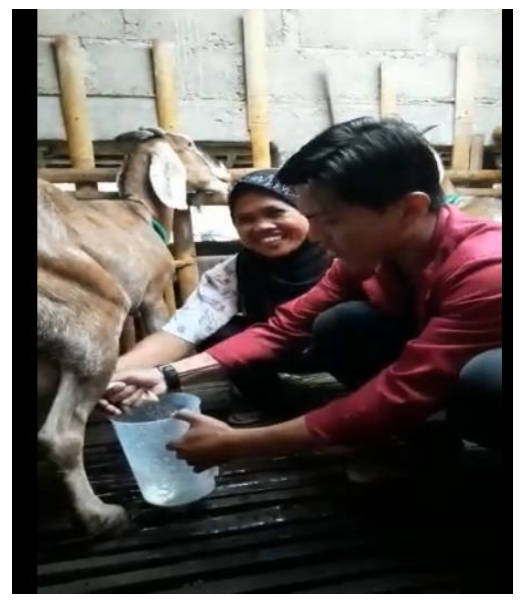

Gambar 3. Proses Pemerasan Susu Kambing Etawa untuk kemudian diproses

Dalam pelaksanaannya, ada beberapa kendala yang yang sempat dihadapi, di antaranya jadwal rencana kegiatan program yang bertabrakan dengan jadwal rutinitas masyarakat setempat. Akhirnya, dengan berbagai macam usaha, telah terlaksana pelatihan pembuatan produksi susu kambing yang diolah menjadi bubuk sehingga susu kambing etawa yang pada hakekaktnya tidak tahan lama. Dengan diolah menjadi bubuk dan dikemas dalam botol yang hampa udara dengan aneka rasa bisa menjadi komoditi ekonomi yang patut menjadi perhatian dan bisa meningkat kesejahteraan ekonomi petani kambing etawa serta menjadi salah satu program unggulan atau penunjang tercapainya sukses Desa Wisata Mrangen. Kendala yang lain adalah keterbatasan anggaran dan waktu dalam membuat tempat produksi yang sesuai dengan standar industri.

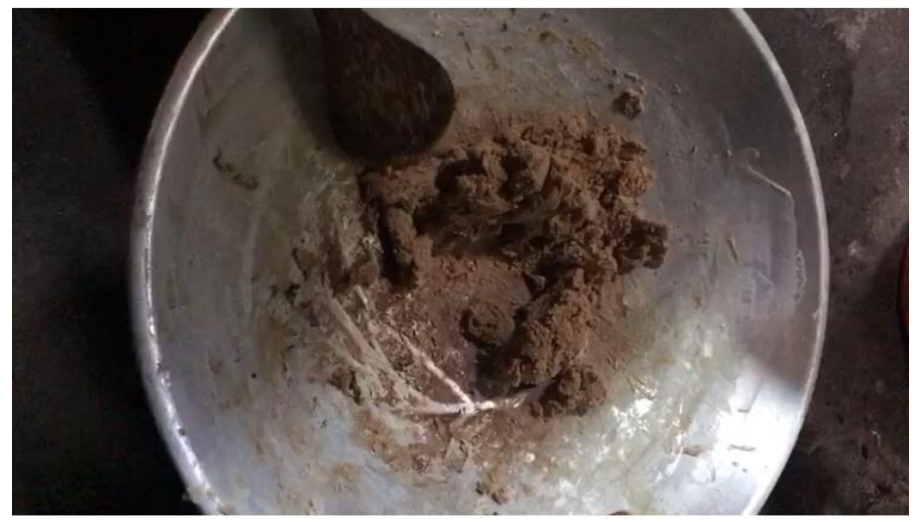

Gambar 4 : Proses pembuatan bubuk dari bahan dasar susu kambing etawa 
Program Pengolahan Susu Kambing Etawa dipilih karena berbagai macam alasan. Salah satunya adalah sebagai usaha dalam meningkatkan produktivitas dusun dan untuk menciptakan mata pencaharian baru. Selain itu, program ini juga sebagai penunjang program desa wisata yang sedang berjalan, yang mampu mewujudkan kotribusi nyata bagi Dusun Rejosari sehingga berdampak positif kepada Desa Mranggen.

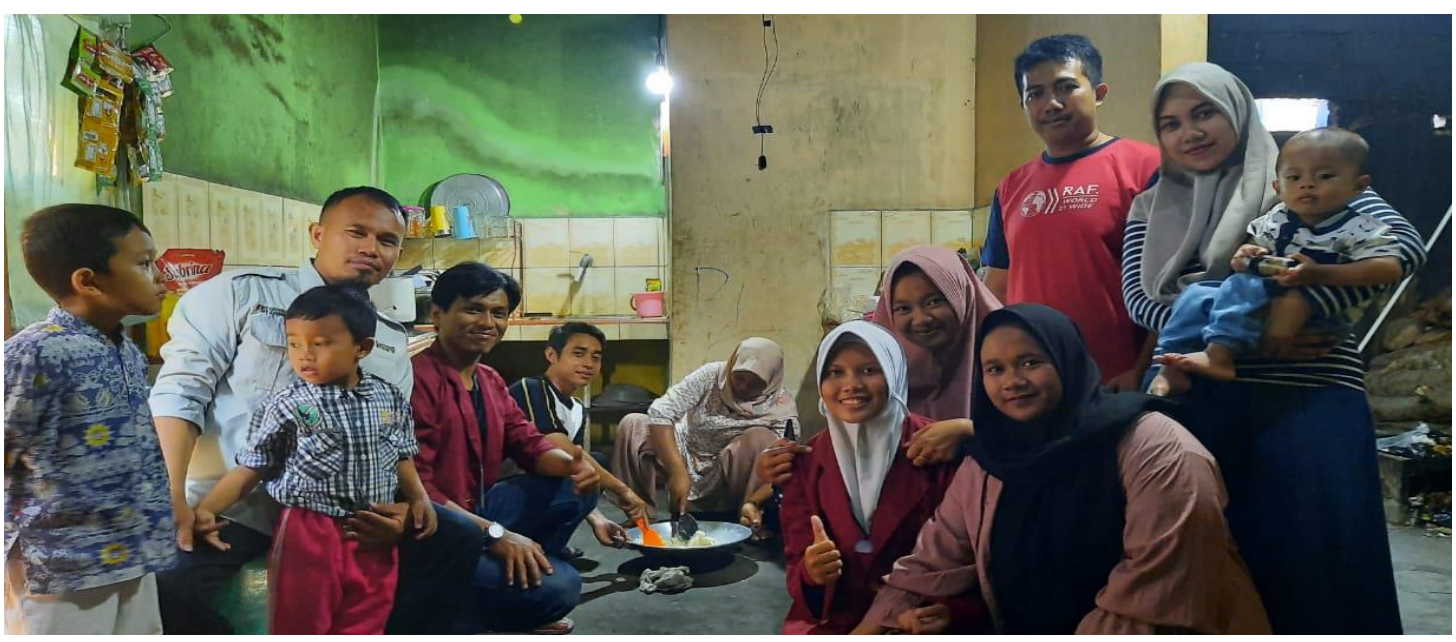

Gambar 5 Gambar 5. Proses pembuatan susu etawa menjadi

Tabulasi Pelaksanaan Program

\begin{tabular}{|c|l|l|l|l|}
\hline No & Nama Program/Kegiatan & Sasaran & $\begin{array}{l}\text { Jumlah Jam Kerja } \\
\text { Efektif }\end{array}$ & Penanggung Jawab \\
\hline 1 & $\begin{array}{l}\text { Pelatihan Pengolahan Susu Kambing } \\
\text { Etawa }\end{array}$ & $\begin{array}{l}\text { Ibu-Ibu di Dusun } \\
\text { Rejosari }\end{array}$ & $\begin{array}{l}\text { Jam } \\
\text { Ketua Pengabdian dibantu } \\
\text { mahasiswa KKN }\end{array}$ \\
\hline
\end{tabular}

Pencapaian Hasil Target

\begin{tabular}{|l|l|l|l|l|l|l|}
\hline No & $\begin{array}{l}\text { Nama Program/ } \\
\text { Keagiatan }\end{array}$ & Sasaran & Target & Keadaan Awal & Keadaan Sesudah & $\begin{array}{l}\text { Tingkat Keberhasilan } \\
(\%)\end{array}$ \\
\hline 1 & $\begin{array}{l}\text { Pelatihan Pengolahan } \\
\text { Susu kambing Etawa }\end{array}$ & $\begin{array}{l}\text { Ibu-ibu di } \\
\text { Dusun } \\
\text { Rejosari }\end{array}$ & $\begin{array}{l}\text { Dihadiri oleh } \\
\text { sedikitnya 30 ibu- } \\
\text { ibu Dusun } \\
\text { Rejosari. } \\
\text { Ibu-ibu teredukasi } \\
\text { dalam pengolahan } \\
\text { susu kambing } \\
\text { etawa. }\end{array}$ & $\begin{array}{l}\text { Masyarakat bisa } \\
\text { mengonsumsi susu } \\
\text { kambing etawa. } \\
\text { Masyarakat belum } \\
\text { mengetahui cara } \\
\text { pengolahan susu } \\
\text { kambing etawa untuk } \\
\text { meningkatakan } \\
\text { produktivitas } \\
\text { dusun. }\end{array}$ & $\begin{array}{l}\text { Ibu-ibu antusias } \\
\text { terhadap pelatihan } \\
\text { kambing etawa }\end{array}$ & $100 \%$ \\
\hline
\end{tabular}

\section{Simpulan}

Pelatihan dan penyuluhan tentang Program Pengolahan Susu Kambing Etawa dipaparkan kepada masyarakat Dusun Rejosari, Desa Mrangen. Masyarakat terlihat antusias.Program ini secara perlahan mampu mengubah pandangan masyarakat akan susu murni kambing etawa yang selama ini terkenal bau dan mudah basi. Pengolahan susu kambing Etawa ini mengubah dari bentuk cair ke bentuk bubuk. Hal ini dilakukan untuk meningkatkn masa kelayakan minum dari batas maksimal dua sampai tiga jam menjadi lebih lama dari itu. Dengan diubah ke dalam bentuk bubuk ini, rasa dari susu kambing etawa menjadi tidak amis sehingga lebih digemari masyarakat. Hal ini terbukti ketika disuguhkan susu kambing etawa olahan kepada masyarrakat 
dalam beberapa acara dan saat ada tamu, mereka menanggapinya antusias dan positif atas hasil kerja ini.

Harapannya adalah sesuatu yang telah kita usahakan dalam pengolahan susu ini mengubah pandangan dan wawasan serta persepsi masyarakat akan rasa dan bau susu kambing etawa. Apabila susu dioalah menjadi produk lain akan lebih baik dan akan lebih mendatangkan nilainilai ekonomis. Hal ini berbeda apabila susu dijual atau diminum murni. Pengolahan susu murni menjadi berbagai produk olahan susu dan aneka rasa bubuk menjadikan produk lebih bervariasi dan pemasarannya pun lebih mudah serta fleksibel sehingga akan menarik wisatawan sebagaimana konsep desa wisata yang sudah menjadi program desa sebagai desa wisata yang bekerja sama dengan LP3M Univesitas Muhammadiyah Yogyakarta.

\section{Ucapan Terima Kasih}

Kami mengucapkan terima kasih atas kerja sama dan bantuan semua pihak yang telah membantu dan bekerja sama dalam menyelesaikan setiap rangkaian pengabdian masyarakat ini, khususnya kepada Lembaga Pendidikan, Penelitian, dan Pengabdian pada Masyarakat (LP3M) Universitas Muhammadiyah Yogyakarta atas Kemitraan Pelaksanaan KKN PPM di Desa Mrangen, pemerintah Desa Mrangen, Magelang atas Kemitraan Program KKN PPM dan Kepala Dukuh Rejosari serta Warga Dusun Rejosari, Desa Mrangen yang telah bersedia bermitra dengan mahasiswa KKN Universitas Muhammadiyah Yogyakarta kelompok 038.

\section{Daftar Pustaka}

Fildzah A'inun N, Hetty Krisnani, \& Rudi Saprudin Darwis, Pengembangan desa wisata melalui konsep community based tourism, Prosiding Penelitian dan Pengabdian kepada Masyarakat, Unpad November 2015.

Bandungan Kecamatan Pakong Kabupaten Pamekasan, JURNAL TEKNIK POMITS Vol. 3, No.2, (2014)

Rusdi 1, Wahidul Basri 2, Aldi Frinaldi 3, Uun Lionar 4, Budidaya Kambing Etawa di Jorong Padang Ambacang Nagari Batu Balang Kecamatan Harau Kabupaten Lima Puluh Kota, Suluah Bendang: Jurnal Ilmiah Pengabdian Kepada Masyarakat Vol.19, No.3, 2019.

Zain, W. N. Kualitas Susu Kambing Segar di Peternakan Umban Sari dan Alam Raya Kota Pekanbaru, Jurnal Peternakan Vol. 10. No. 1. Februari 2013 (24-30. ISSN 1829-8729.

https://www.investasiuntung.com/2017/12/cara-ternak-kambing-etawa-untung.html 